\title{
French versus English: A sociolinguistic study of Moroccans' foreign language attitudinal tendencies
}

\author{
Mahmoud Seddik * \\ (Mohammed V University, Morocco)
}

\begin{abstract}
The complexity of the Moroccan language landscape sparks off a power struggle between languages. The focus in this chapter is on the apparent French/English language contest over supremacy. Here comes the current investigation that aims at gauging Moroccan's perceptions of French and English through a language questionnaire. Responses were subjected to statistical analyses to support or reject the hypothesis that gender, age and language proficiency affect Moroccans' evaluations of French and English. The study reveals that Moroccans' attitudes towards English are significantly more favorable than those towards the French language. Age, but not gender, has turned out to have a statistically significant difference in the overall evaluation of French and English. These evaluations have also been shown to correlate with the respondents' French and English language proficiency. The result of this study is an indication that Moroccans' attitudes toward French and English are undergoing a change from a conventional preference for French to a recent favor of English whose phenomenal growth globally may have affected language attitudes locally.
\end{abstract}

Keywords: language attitudes, tendency, evaluation, solidarity, status

\section{Introduction}

Being a French protectorate for more than four decades, Morocco added another language to its linguistic tapestry. The French language, Morocco's first foreign language or second language, has been perceived by pro-French groups as a spoil of war and therefore it should be maintained. However, for the anti-French groups, it was regarded as "the colonizer's language" and therefore it should be replaced. The English language has been hailed for as the appropriate replacer given the fact that the prestige and the status that the French language has been enjoying within the Moroccan collective attitude is believed

\footnotetext{
* Dr. Mahmoud Seddik: Professor, Faculty of Sciences of Education, Mohammed V University, Rabat. His research interests include Applied Linguistics, Sociolinguistics, Language Ideology. Email: Mahmoud_ sadik25@yahoo.com.
} 


\section{Mahmoud Seddik}

to be fading away under the dramatic growth of English.

In this respect, this article aims firstly at reviewing some of literature on the Moroccan linguistic scene as well as some of the language attitude studies and then introducing the research instruments used to test the hypothesis that the seemingly Moroccans' foreign language attitudinal shift from esteeming the French language to favoring English is being affected by the variables of age, gender and language proficiency.

\section{Review of literature}

\subsection{French and English within the Moroccan sociolinguistic scene}

During the 44-years-French protectorate of Morocco, the French colonial administration insisted on imposing their language as a means of instruction in schools and a medium of communication in administration. As a consequence, a western lifestyle has been adopted and new values have been introduced. Speaking French has become tantamount to professional and social elevation, and a speaker of this foreign language is usually perceived as intellectual, civilized and elegant. Socio-linguistically speaking, French has long been held as a language of power (Bentahila, 1983; Marley, 2004).

But today, the French language's consensual superiority in Morocco is at stake because of the rise of the English language that seems in a position to compete with the French language in many realms of life of the Moroccan society. Unlike French, English is free from any colonial connotations or cultural imposition for Moroccans; instead, it is prized for its instrumental value as a key to the outside world. Sadiqi (1991:111) states that, "being a colonial language, French has inevitably been considered a symbol of political and cultural dependence, although this is not explicit. The rather negative attitude toward French indirectly increases the popularity of (and hence the positive attitude toward) English, a language without any colonial connotations". Indeed, the Moroccan endeavors to liberalize telecommunications, expand internet access, and diversify its economy have contributed to this surge in exposure to English and the growing demand for English language education.

\subsection{Definitions of language attitude}

It was in the 1950s that language attitudes started to be the focus of investigation among social psychologists. The adoption of the mentalist approach that considered language production as cognitive or mental activity, and not as behavior, motivated and increased the interest in understanding language attitudes. A satisfactory definition of language attitude is offered by Ryan, Giles \& Sebastian (1982), who defined the concept as "any affective, cognitive or behavioral index of evaluative reactions towards different language varieties or their speakers". In the context of second or foreign language learning, the learner has certain perceptions and beliefs about the target language that will influence his/her attitudes 
and consequently the learning process. Gardner (1985:40) differentiates between attitudes towards learning the language and the language community itself. It is very common knowledge in sociolinguistics and psycholinguistics that people make a number of inferences from someone's language features. Studies like that of Ryan, Giles \& Sebastian (1982) have shown that listeners infer traits about speakers from their choice of language, dialect and paralinguistic features. In the Moroccan sociolinguistic sphere, a person who juggles between MA, SA and French is likely to be regarded as a person of intellectuality, social mobility and high status. Theoretically, Appel \& Muysken (1987:12) state that "if language has social meaning, people will evaluate it in relation to the social status of its users". In most research (Ryan, Giles \& Sebastian, 1982; Appel \& Muysken, 1987), attitudes towards a particular language are taken to be reflections of attitudes towards the speakers of that specific language.

\section{Methodology}

As noted earlier in this paper, the current study is conducted to test the hypothesis that there is a foreign language attitudinal shift among Moroccans from French to English language preference. The study aims at answering the following research questions:

\subsection{Research questions}

(a) Are Moroccans' attitudes shaping up towards favoring English over French?

(b) Does the respondents' French and English language proficiency have any influence on their evaluations of the two languages?

(c) Does gender affect Moroccans' attitudinal perceptions of French and English?

(d) Does age have any impact on the Moroccans' attitudes towards French and English?

\subsection{The instruments and the procedures}

A questionnaire was designed in a five-layered way (see Appendix). The first section of the questionnaire focuses on the respondents' general background. The second section seeks to explore the participants' French and English language mastery. The third part seeks to investigate their attitudes towards French and English in the light of a set of status and solidarity traits. The fourth part of the questionnaire tries to elicit information about the frequency of French and English language use in day-to-day life. The fifth section addresses the participants' French and English learning experiences.

\subsection{Respondents}

The questionnaire was administered to 326 participants, distributed as follows: 198 were females and 128 were males. 242 were less than 25 of age belonging to three institutions: Cherif El Idrissi Preparatory Classes in Taza, Alfalah School Group in Taza, Mohammed Ben Abdallah University in Fez and the other 84 respondents were above 45 of age. The choice of age as a variable in this study and particularly these two categories is strategic. 


\section{Mahmoud Seddik}

There is a considerable number of Moroccans who belong to the pre-Arabization era when French was, until the 80 s, totally or partially the language of instruction in Moroccan schools; the fact that makes us postulate that those above 45 years old may have some sort of nostalgia and/or loyalty to the language they have been instructed with. Therefore, such a tendency may influence their attitudes positively towards French and less positively towards English.

\section{Results of the language questionnaire}

\subsection{Background data}

Concerning gender, 198 out of 326 participants were females (60.7\%) while males constituted the remaining 39.3\% (128 participants). As for age, there were two populations as far as their age is concerned, the first group's age ranges from 16 to 25 and it was labeled 'Less than 25' and the second group's age ranges from 45 to 60 of age and it was labeled 'Above 45 ' of age. 242 out of 326 participants (74.2\%) were less than 25 and the remaining 84 (25.8\%) were above 45.

\subsection{Foreign language proficiency}

As far as the French language is concerned, the results show that 157 of the respondents (48.2\%) think that they have a poor or very poor level in French while 113 of them (34.7\%) believe that they are of an average level whereas 56 of the participants (17.2\%) claim that they do have a good or very good level in the French language. In other words, 33.4\% of the participants who believe that their French level is average, good or even very good are females while males form $18.4 \%$ of the participants who think their level is average, good or even very good. The results also show that females constitute $27.3 \%$ of those who think that they have a poor level in French while males form 20.8\% of those believing that they have a poor level in French. As for age, it has been shown that $22.5 \%$ of the participants who think that they have an average, good or even a very good level in French are above 45 of age and only $3.4 \%$ of the respondents of the same age category think that they have a poor level. In comparison, $37.5 \%$ of the participants who feel that they are of an average, good or even very good level in French are less than 25 of age and $44.8 \%$ of the respondents of the same age category think that they have a poor or even very poor level.

As for the English language, the results show that 73 of the respondents (22.4\%) think that they have a poor or very poor level, 127 of them (30.1\%) believe that they are of an average level while 126 of the participants $(38.7 \%)$ claim that they do have a good or very good level in the English language. $47.5 \%$ of the participants who believe that their English level is average, good or even very good are females while males form $30.1 \%$ of the participants who think their level is average, good or even very good. The results also show that females constitute $13.2 \%$ of those who think that they have a poor level in 
English while males form 9.2\% of those believing that they have a poor level in English. As for age, $11 \%$ of the respondents who think that they have an average, good or even a very good level in English are above 45 of age and 14.7\% of those with the same age category think that they have a poor level. In comparison, $66.5 \%$ of the participants who feel that they are of an average, good or even very good level in English are less than 25 of age and $7.6 \%$ of those in the same age category think that they have a poor or even very poor level.

All in all, through a separate self-evaluation of French proficiency and English proficiency, the majority of the respondents, regardless of their age and gender, think that their French and English proficiency range from average to good. Concerning age, the respondents above 45 years think that their level in French is better than their level in English whereas those less than 25 of age believe that their level in English is far better than French. This English proficiency among young Moroccans was expected in this study, given the phenomenal spread of English globally and locally, the growing interest to learn it, wide exposure among teenagers and adults to English language media, the spread of English language centers, and educational legislations to improve its status as a school subject. All these factors encourage young Moroccans to be proficient in English. Concerning gender, the females feel that their French and English language level is between average and good, surpassing their male counterparts.

\subsection{Attitudes towards French and English}

The data presented in this section reports the informants' attitudes towards French and English in general as well as on the solidarity and status dimensions in particular. The questionnaire included a checklist of six statements about French and English which informants had to rate on a five - points Likert scale: strongly disagree, disagree, neutral, agree, and strongly agree (Likert, 1932). These are the traits classified into solidarity and status categories:
Solidarity
traits
(a) Fre/Eng is a rich language
(b) Fre/Eng is a beautiful language
(c) Fre/Eng is helpful in communication
Status
(d) Fre/Eng is a global language
(e) Fre/Eng helps modernization
(f) Fre/Eng helps in the job market

Table 1 reports the participants' responses regarding their attitudes towards the six statements about French and English. The alphabets (a, b, c, d, e, f) on the left side of the table are codes that refer to the six traits above.

The respondents' evaluations of the two languages based on the first three solidarity items seem to be more favorable towards French than English. To explain, regarding the quality of being a rich language, the participants' responses are split almost equally into two categories. $40 \%$ of the participants agree or strongly agree with the idea that French is 


\section{Mahmoud Seddik}

a rich language while another $41.10 \%$ disagree or strongly disagree with it. As for English, the results obtained show that $72.39 \%$ of the respondents are in favor of the idea that English is a rich language compared to $9.20 \%$ of the responses that have a different opinion. As for the second statement, $57.36 \%$ of the informants agree or strongly agree that French is a beautiful language while only $23.92 \%$ of them disagree or completely disagree with it. Concerning English, $42.63 \%$ of the participants disagree or strongly disagree with it and a surprising $55.82 \%$ have no opinion about this very point while only $1.53 \%$ think that English does have some beauty. Almost similar results are about the third item for only $5.82 \%$ of the respondents agree that English could be of help in their daily interactions while $73.92 \%$ of them express disagreement. In stark contrast, French is perceived differently as $69.32 \%$ of the participants believe that French is helpful in their daily communication. It is very noticeable that there is almost a consensus among the respondents that French constitutes an integral part of their daily communication.

Table 1. The overall self-evaluations of French and English

\begin{tabular}{|c|c|c|c|c|c|c|c|c|c|c|c|}
\hline \multirow{2}{*}{ Language } & \multirow{2}{*}{ Trait } & \multicolumn{2}{|c|}{ Strongly Disagree } & \multicolumn{2}{|c|}{ Disagree } & \multicolumn{2}{|c|}{ Neutral } & \multicolumn{2}{|r|}{ Agree } & \multicolumn{2}{|c|}{ Strongly Agree } \\
\hline & & $\mathrm{N}$ & $\%$ & $\mathrm{~N}$ & $\%$ & $\mathrm{~N}$ & $\%$ & $\mathrm{~N}$ & $\%$ & $\mathrm{~N}$ & $\%$ \\
\hline \multirow{6}{*}{ French } & (a) & 29 & $8.89 \%$ & 104 & $31.90 \%$ & 61 & $18.71 \%$ & 116 & $35.58 \%$ & 16 & $4.90 \%$ \\
\hline & (b) & 15 & $4.60 \%$ & 63 & $19.32 \%$ & 61 & $18.71 \%$ & 161 & $49.38 \%$ & 26 & $7.97 \%$ \\
\hline & (c) & 2 & $0.61 \%$ & 83 & $25.46 \%$ & 15 & $4.60 \%$ & 155 & $47.54 \%$ & 71 & $21.77 \%$ \\
\hline & (d) & 90 & $27.60 \%$ & 111 & $34.04 \%$ & 7 & $2.14 \%$ & 88 & $26.99 \%$ & 30 & $9.20 \%$ \\
\hline & (e) & 109 & $33.43 \%$ & 163 & $50 \%$ & 8 & $2.45 \%$ & 46 & $14.11 \%$ & 0 & $0 \%$ \\
\hline & (f) & 7 & $2.14 \%$ & 18 & $5.52 \%$ & 13 & $3.98 \%$ & 158 & $48.46 \%$ & 130 & $39.87 \%$ \\
\hline \multirow{6}{*}{ English } & (a) & 2 & $0.61 \%$ & 28 & $8.58 \%$ & 60 & $18.40 \%$ & 162 & $58.89 \%$ & 74 & $22.69 \%$ \\
\hline & (b) & 112 & $34.35 \%$ & 27 & $8.28 \%$ & 182 & $55.82 \%$ & 5 & $1.53 \%$ & 0 & $0 \%$ \\
\hline & (c) & 78 & $23.92 \%$ & 163 & $50 \%$ & 66 & $20.24 \%$ & 18 & $5.52 \%$ & 1 & $0.30 \%$ \\
\hline & (d) & 0 & $0 \%$ & 0 & $0 \%$ & 3 & $0.92 \%$ & 115 & $35.27 \%$ & 208 & $63.80 \%$ \\
\hline & (e) & 0 & $0 \%$ & 6 & $1.84 \%$ & 0 & $0 \%$ & 113 & $34.66 \%$ & 207 & $63.49 \%$ \\
\hline & (f) & 1 & $0.30 \%$ & 22 & $6.74 \%$ & 0 & $0 \%$ & 92 & $28.22 \%$ & 211 & $64.72 \%$ \\
\hline
\end{tabular}

Regarding the second three status traits, English seems to enjoy a higher status than French among the respondents. To illustrate, concerning whether or not French and/or English are international languages, $61.65 \%$ of the informants refuse to attribute that quality to French while a sweeping majority of $99.07 \%$ of the answers are in favor of English being an international language. Similarly, there is almost an agreement among the respondents that English (98.15\%) and French (83.43\%) can facilitate the process of integrating into and following modernization. The last item that French and English can be helpful to integrate into the job market receives almost the same response from almost 
all the participants for both languages. Specifically, $88.34 \%$ of the participants think that French helps in the job market and another $92.94 \%$ of them agree or strongly agree with the idea that English can play that role.

In a nutshell, the figures and statistics elaborated above are drawn from a total of 3912 responses to the six solidarity and status traits about French and English. Regarding French, among the 1956 responses to the six statements, $50.97 \%$ are in agreement with those items while $40.38 \%$ express disagreement. As for English, $61.65 \%$ of the total responses are in agreement with the six traits. Therefore, these results are indicative of a positive attitude among the respondents towards French and very favorable attitudes towards English.

In order to verify whether such differences between the respondents' evaluation of French and their evaluation of English are statistically significant or not, the Wilcoxon test shows that, except for the second item $(Z=-1.523, p=0.128)$, the difference seem highly significant for the other five pairs.

Table 2. Wilcoxon signed-rank test of the respondents' evaluations of French and English

\begin{tabular}{l|l|l|l|l|l|l}
\hline Trait & (a) & (b) & (c) & (d) & (e) & (f) \\
\hline $\mathrm{Z}$ & $-9.117^{\mathrm{b}}$ & $-1.523^{\mathrm{c}}$ & $-13.660^{\mathrm{c}}$ & $-13.671^{\mathrm{b}}$ & $-14.700^{\mathrm{b}}$ & $-4.566^{\mathrm{b}}$ \\
\hline Asymp. Sig. (2-tailed) & .000 & .128 & .000 & .000 & .000 & .000 \\
\hline
\end{tabular}

These results support the first research question of whether or not the Moroccans' language attitudinal disposition is shaping up towards favoring English over French. In other words, there seems to be a new foreign language attitudinal pattern under construction characterized by English gaining ascendancy and French losing its long-held supremacy. This brewing language attitudinal disposition is indicative of the Moroccans' mindfulness of the supremacy of the English-speaking world in the field of business, science, art, education and technology. For the respondents, a mastery of English seems like possessing a symbolic capital that would guarantee a promising future either in business, in communication and/or in education. Moreover, Moroccans' widespread exposure to English TV programs, social media and English language movies may also have an enormous impact on the respondents' language attitudinal construction.

By and large, the questionnaire results seem to suggest that regardless of the respondents' attitudes towards French and English based on the six statements, their overall evaluation of French and English seems to be favorable. They have a dubiously positive attitude toward French whereas they seem to have an unequivocal positive attitude towards English regarding the six statements. Generally, the respondents' language attitudes toward English seem more positive than their attitudes towards French.

Moroccans, for decades, have perceived French as a language of high status, social 


\section{Mahmoud Seddik}

mobility and prestige. However, the results revealed in this study seem to suggest that those attitudes towards French need to be verified in the light of the incontrovertible spread of English in Morocco. That is to say, the high position that French has been holding in the Moroccan language attitudinal level is being challenged by English that has started earning qualities of prominence and superiority.

The impression that the respondents hold more favorable attitudes towards English than French turned out to be more than just a general mood or a public fashion. This foreign language preference for English is proved to be a significantly growing tendency among the respondents and a pragmatically deliberate trend to place English at the top of the Moroccan language status hierarchy. In this regard, one may wonder what variables might have an impact on this tendency. The following section will be devoted to an examination of whether or not gender and/or age have any influence on the respondents' evaluations of French and English.

\subsection{Gender and attitudes towards French and English}

The aim of this section is to determine if gender has any impact on the respondents' evaluations of French and English. For organizational purposes, the presentation will start with the respondents' evaluations of French and then English.

The female and the male respondents seem to have rated the two languages differently on the first three solidarity traits. To explain, the results show that $50.50 \%$ of the female respondents agree $(42.92 \%)$ or strongly agree $(7.57 \%)$ with the view that French is a rich language while only $25 \%$ of the male respondents have a similar view. As far as the second item is concerned, $61.61 \%$ of the female respondents agree or strongly agree with the view that French is a beautiful language and $50 \%$ of the male respondents agree or strongly agree with that opinion. As for the third item, the results show that $76.26 \%$ of the female respondents agree or strongly agree with the idea that French is helpful in their daily interaction while the males who share that view constitute only $58.59 \%$. Generally, the respondents evaluate French favorably on the solidarity dimension. Out of 978 responses, $55.72 \%$ of them concur that French is a rich, beautiful and helpful language in daily communication while $30 \%$ of the responses disagree with those items.

Gender is shown to have a significant impact on the respondents' evaluations of the three solidarity traits. Specifically, the Chi square test of association shows that there is a statistically significant association between gender and the respondents' attitudes towards 'French being a rich language' $\left(X^{2}(4)=56.639, p<.005\right)$, towards 'French being a beautiful language' $\left(X^{2}(4)=28.286, p<.005\right)$ and towards 'French being helpful in their daily conversations' $\left(X^{2}(4)=30,744, p<.005\right)$.

The clearest idea that emerges from these meaningful statistics is that French is perceived better by the female than the male informants on the solidarity dimension. That 
is to say, the female respondents seem to regard French as a language that enjoys some sort of familiarity more than their male counterparts. Such an inclination on the part of the female respondents to regard French as rich, beautiful and helpful in communication may emanate from their feminine nature. Commonly, attributes such as diversity, beauty and sociability hold some allure for females more than males. It is maybe for this possible reason that French seems to enjoy characteristics of closeness and intimacy among the female respondents more than the male respondents.

The significant presence of the female respondents in solidarity evaluation of French seems active also in the respondents' evaluation of French on the status items. To explain, the figures show that $83.59 \%$ of the male respondents agree or strongly agree with the idea that French is a global language while only $13.13 \%$ of the female respondents share the same view. As far as the fifth item is concerned, $16.16 \%$ of the female respondents accept the view that 'French helps follow modernization' whereas $23.43 \%$ of the male respondents agree or strongly agree with that opinion. As for the last item, the results reveal that $92.92 \%$ of the female respondents agree or strongly agree with the view that 'French is important in the job market' while males who confirm that view constitute $81.25 \%$. In general, out of 978 responses, $50.92 \%$ of them disagree or strongly disagree with the view that French is an international language, useful in a global era and helpful in the job market while $46.21 \%$ of the respondents agree or strongly agree with these items. Precisely, the female respondents $(40.20 \%)$ perceive French of less status than their male counterparts $(62.76 \%)$.

Similar to solidarity dimension, gender proves to have a significant influence on the respondents' evaluations of all the three status traits. To clarify, the Chi square test of association shows that there is a significant association between gender and the respondents' attitudes towards' French being an international language' $\left(X^{2}(4)=165,866, p<.005\right)$, towards 'French being helpful to follow modernization' $\left(X^{2}(4)=18.846, p<.005\right)$ and towards 'French being important in the job market' $\left(X^{2}(4)=15.826, p<.005\right)$.

It is clear that the female respondents evaluate French unfavorably on the status dimension more than their male counterparts. That is to say, French seems to start losing its characteristics of prestige, power and superiority especially among females. A comparison with the results pertaining to solidarity evaluation, one may get an impression that female respondents might be more conscious of the value of language, alert to its subtleties and, therefore, more likely to respond with favor or disfavor than the male respondents. Another pattern that is elicited from such comparison is the possible correlation that might exist between the respondents' solidarity and status evaluation of French. To put it differently, just like a weighing scale, the better the solidarity plate/items are evaluated, the less the status plate/traits are evaluated. Also, the females' role in this correlation seems pivotal. They are the ones who seem to drive the new language attitudinal tendency to remove 


\section{Mahmoud Seddik}

French from a language of high status, useful in higher domains, to lower status, useful in lower domains.

Dissimilarity is also a quality that characterizes the females' and the males' evaluations of English based on the three solidarity traits. To illustrate, concerning 'English being a rich language', the results show that $66.15 \%$ of the female respondents agree or strongly agree with the view that English is a rich language while $82.03 \%$ of the male respondents have a similar view. As far as the second item is concerned, $64.14 \%$ of the female respondents agree or strongly agree with the view that 'English is a beautiful language' while $46.87 \%$ of the male informants agree or strongly agree with that opinion. Concerning the item that 'English is helpful in daily communication', 6.05\% agree and or strongly agree with the item compared to $5.46 \%$ of the males who share a similar view. Generally, only $26.58 \%$ of the total responses concur that English is a rich, beautiful and a helpful language in the respondents' daily communication and $41.54 \%$ of the respondents disagree with those items. In relation to gender, an almost equal percentage of the female respondents $(45.45 \%)$ and the male respondents $(44.79 \%)$ seem to share almost equally a similar opinion that English is a language of less familiarity for them.

The respondents' evaluation of English is shown to be significantly influenced by the variable of gender. More specifically, the Chi square test of association shows that there is a significant association between gender and the respondents' attitudes towards 'English being a rich language' $\left(X^{2}(4)=16.123, p<.005\right)$, towards 'English being a beautiful language' $\left(X^{2}(3)=12.562, p<.005\right)$ and towards 'English being helpful in daily conversations' $\left(X^{2}(4)=22.225, p<.005\right)$.

In the light of these meaningful results, English, unlike French, is perceived less positively on the solidarity dimension. This predictable outcome finds its justification in the little contact that the respondents have with English. The language is still being viewed as a school subject that students should master mostly to pass exams. Surprisingly, though this very little contact, English seems to be perceived favorably on the solidarity traits as if there is some sort of familiarity and intimacy with the respondents.

Unlike the solidarity dimension, the respondents' status evaluation of English reflects some agreement in their opinion. The results obtained reveal that $97.65 \%$ of the male respondents agree or strongly agree with the view that 'English is a global language' and $100 \%$ of the female informants hold a similar view. As far as the fifth item is concerned, the results above show that $100 \%$ of the female respondents agree or strongly agree with the view that 'English helps follow modernization' and $95.31 \%$ of male respondents agree or strongly agree with that opinion. As for the sixth item, $94.44 \%$ of the female respondents agree or strongly agree that 'English is important in the job market' and the male informants who confirm that view constitute $90.62 \%$. In general, out of 978 responses, the 
sweeping majority of $96.72 \%$ of them agree or strongly agree with the view that English is an international language, helps follow modernization and is helpful in the job market. In relation to gender, $98.30 \%$ of the female respondents think that English enjoys high status, which is a little higher than the male respondents $(94.53 \%)$ who think so.

Unlike the solidarity dimension, gender does not seem to have an influence on the respondents' evaluations of all the three status items. Through a Chi square test of association, a significant association was found between gender and the respondents' attitudes towards 'English being a global language' $\left(X^{2}(2)=12.116, p<.005\right)$, and towards 'English being helpful to follow modernization' $\left(X^{2}(2)=9.666, p<.005\right)$, but no association was found between gender and the respondents' attitudes towards 'English being important in the job market' $\left(X^{2}(3)=3.428, p=.330\right)$.

Obviously, given these statistically meaningful differences, English was evaluated more favorably on the first two status dimension by the female respondents than their male counterparts. For the informants' conceptual perception, it seems that English enjoys a high status, which is indirectly a translation of the respondents' awareness of the universality of the language that made it the world's lingua franca and a means to develop or modernize. As was the case with French evaluation, the female respondents' touch is so visible in the English status evaluations as well even if it is not as plain as their role in the French status evaluation. The nonsignificant effect of gender on the evaluation of the third statement that English is helpful in the job market finds its explanation in the kind of conflict between theory and practice, between vision and present. Theoretically, the informants may have envisioned English as a useful language in the Moroccan job market in their near future, but practically, it has not reached that position yet. Also, the ambiguity or impracticality of this idea in the present time is reinforced by the respondents' status evaluation of English that was perceived positively by an extreme majority of the respondents.

To conclude, the Chi-square tests of the association carried out for each of the six items about French and English were meant to provide an accurate and reliable answer to the second research question whether or not gender does have an impact on the respondents' attitudes towards French and English. The results obtained confirm that, except for the statement that 'English is important in the job market', there was a significant association between gender and the respondents' attitudes towards French and English. Thus, the null hypothesis that gender has no effect on the overall evaluation of French and English is rejected and the alternative hypothesis is accepted.

\subsection{Age and attitudes towards French and English}

The aim of this section is to determine if age has any influence on the respondents' evaluations of French and English based on the six items provided for the respondents.

The respondents of both age groups seem to have different attitudes towards French 


\section{Mahmoud Seddik}

based on the three solidarity items. To explain, $80.95 \%$ of the respondents 'above 45 ' of age agree or strongly agree with the view that 'French is a rich language' while only $26.44 \%$ of the respondents 'below 25' of age share a similar view. As far as the second item is concerned, $86.90 \%$ of the respondents 'above 45 ' years agree or strongly agree with the idea that 'French is a beautiful language' whereas $47.10 \%$ of the respondents 'below 25 ' years agree or strongly agree with that opinion. As for the third item, $85.71 \%$ of the respondents 'above 45' of age concur with the view that French is 'helpful in their daily communication' while those 'below 25' of age who confirm that view constitute $63.63 \%$. Overall, French has been perceived very positively on the solidarity dimension by $84.52 \%$ of the respondents 'above 45 ' of age while only $40.73 \%$ of the respondents 'less than 25 ' of age have a positive attitude towards French on the three solidarity traits.

Age is shown to have a significant impact on the respondents' solidarity evaluation of the French language. In that, the Chi Square test of association shows a statistically significant difference between age and the respondents' attitudes towards the views that French is 'a rich language' $\left(X^{2}(4)=56.639, p<.005\right)$, 'a beautiful language' $\left(X^{2}(4)=\right.$ $46.565, p<.005)$, and 'helpful in daily communication' $\left(X^{2}(4)=30.744, p<.005\right)$.

The clearest pattern that comes out of these meaningful statistics is the older the person, the higher French can be rated and the younger the person, the lower French can be rated. That is to say, the elderly participants seem to have built, through the course of their academic, professional and social life, a fairly strong connection with French. On the other hand, the younger generation's shaky connection with French might be the result of the growing pop culture empowered and stimulated by the English language that they seem to start a process of familiarizing with.

The respondents' status evaluations of French can be characterized as somehow harmonious. More precisely, $36.90 \%$ of the respondents 'above 45 ' years agree or strongly agree that 'French is a global language' and $42.14 \%$ of the respondents 'below 25 ' express a similar view. As far as the fifth item is concerned, $55.95 \%$ of the respondents 'above 45 ' years agree or strongly agree with the view that 'French helps follow modernization' while only $6.19 \%$ of the respondents 'below 25 ' years agree with that opinion. Concerning the sixth item, $89.28 \%$ of the respondents 'above 45 ' of age concur with the idea that 'French is important in the job market' and $88.01 \%$ of those 'below 25 ' of age confirm that view. In short, $60.71 \%$ of the respondents 'above 45 ' of age express favorable attitudes towards French on the status traits while only $45.45 \%$ of those 'below 25 ' of age have similar attitudes.

Unlike gender, age does not seem to have an impact on the respondents' evaluations of all the three status traits. The Chi square test of association reveals that there is a statistically significant difference between age and the respondents' attitudes towards the 
view that French helps follow modernization $\left(X^{2}(4)=108.936, p<.005\right)$ and 'French is important in the job market' $\left(X^{2}(4)=12.481, p<.005\right)$, but the test shows no evidence to suggest that there is an association between age and the respondents' attitudes towards 'French being a global language' $\left(X^{2}(5)=6.242, p=.283\right)$.

The pattern observed in the respondents' solidarity evaluation of French is repeated in their status evaluation. The younger the person, the lower rates French can be given on the status traits and vice versa. That is to say, French has lost its long-held attributes of superiority and power at least among the younger generations.

Regarding English, the respondents of both age groups seem to hold different attitudes towards English based on the three solidarity traits. In that, $81.40 \%$ of the informants 'below 25' of age express their agreement or strong agreement with the view that 'English is a rich language' whereas $45.42 \%$ of those 'above 45 ' age group have the same opinion. Concerning 'English is a beautiful language', $63.63 \%$ of those 'below 25 ' years agree or strongly agree while only $39.28 \%$ of those 'above 45 ' of age show agreement with that item. Regarding the third statement, it has been noticed that no one of those 'above 45 ' of age agree that English helps them in their daily conversations and a minority of $7.87 \%$ of those 'below 25' of age do have a similar opinion. In brief, English is perceived favorably by $50.92 \%$ of the respondents who belong to 'below 25 ' age group while only $28.57 \%$ of those 'above 45 ' of age have similar attitudes.

Age is shown to have a statistically significant impact on the respondents' solidarity evaluations of English. The Chi square test of association reveals that there is a statistically significant difference between age and the respondents' attitudes towards the items that 'English is a rich language': $\left(X^{2}(4)=58.847, p<.005\right)$, 'English is a beautiful language': $\left(X^{2}(3)=16.827, p<.005\right)$ and 'English is helpful in daily communication': $\left(X^{2}(4)=\right.$ $17.183, p<.005)$.

Status evaluation of English, on the other hand, seems to reflect some kind of agreement among the respondents. To explain, we notice a remarkable unanimity among the 'below 25 ' age group that 'English is a global language' and almost a similar consensus (96.42\%) among those 'above 45' of age. Moreover, there is almost a consensus among those 'below 25 ' age group (98.75\%) and those 'above 45' age group (96.42\%) that 'English helps follow modernization'. Also, $75 \%$ of the respondents 'above 45' of age admit that 'English is useful in the job market' and there is approximately a total agreement (99.17\%) with that view among those 'below 25' of age. In short, English has been perceived very favorably on the three status traits by $99.31 \%$ of the respondents 'below 25 ' of age, which is a bit higher than the $89.28 \%$ of the respondents 'above 45 ' of age who had a positive attitude towards English on the status dimension.

Age turns to have an influence on the respondents' attitudes towards the three status 


\section{Mahmoud Seddik}

items. The Chi square test of association shows that there is a statistically significant difference between age and the respondents' attitudes towards the view that 'English is a global language' $\left(X^{2}(2)=29.514, p<.005\right)$, 'English helps follow modernization' $\left(X^{2}(2)=\right.$ $96.625, p<.005)$, and 'English is important in the job market' $\left(X^{2}(3)=95.672, p<.005\right)$ ').

To sum up, the Chi-square tests of the association carried out were meant to provide an accurate answer to the third research question whether or not age has an impact on the respondents' attitudes towards French and English. The results obtained confirm that, except for the statement that 'French is an international language', there was a significant association between age and the respondents' attitudes towards French and English. Thus, the null hypothesis that age has no effect on the overall evaluation of French and English is rejected and the alternative hypothesis is accepted.

Understanding the respondents' language attitudinal tendency to English preference can be obtained not only through one's direct perception of the language, but also indirectly through their opinion about numerous topics related, in a way or another, to French or English.

\subsection{Foreign language proficiency and attitude towards French and English}

To see if there is any correlation between the respondents' overall evaluation of the French language as well as the English language and their proficiency level in those languages, Pearson correlation coefficient was computed. The result revealed, as evidenced in Table 3, that there is a statistically significant correlation between the respondents' French language proficiency and their attitudes towards French: $r=0.266, n=326, p=$ 0.000 . The results also show that there is a statistically significant correlation between the respondents' English language proficiency and their attitudes towards English: $r=0.293, n$ $=326, p=0.000$.

This correlation, which is a positive correlation $(+)$, indicates that as one variable increases in value, the second variable also increases in value. Similarly, as one variable decreases in value, the other one also decreases. That is to say, the higher a person's level in a language, the more positive his attitudes towards that specific language. Similarly, the lower a person's level towards French and English is, the less positive his/her attitudes towards those languages will be.

More interestingly, the correlation table shows that there is also a statistically significant correlation between: (a) The respondents' French language proficiency and the English language proficiency $(r=-0.235, n=326, p=0.000)$. (b) The respondents' English language proficiency and their attitudes towards French $(r=-0.235, n=326, p=0.000)$. (c) The respondents' French language proficiency and their attitudes towards English $(r=$ $-0.235, n=326, p=0.000$ ). (d) The respondents' attitudes towards French and English ( $r=$ $-0.235, n=326, p=0.000)$. 
French versus English: A sociolinguistic study of Moroccans'foreign language attitudinal tendencies

Table 3. Correlations between the respondents' evaluation of the French guise and French proficiency and the respondents' evaluation of the English guise and English proficiency

\begin{tabular}{|c|c|c|c|c|c|}
\hline & & $\begin{array}{c}\text { French } \\
\text { proficiency }\end{array}$ & $\begin{array}{c}\text { Attitude } \\
\text { towards French } \\
\end{array}$ & $\begin{array}{c}\text { English } \\
\text { proficiency }\end{array}$ & $\begin{array}{c}\text { Attitude towards } \\
\text { English } \\
\end{array}$ \\
\hline \multirow{3}{*}{$\begin{array}{l}\text { French } \\
\text { proficiency }\end{array}$} & Pearson Correlation & 1 & .266 & $-.235^{* *}$ & $-.323^{* *}$ \\
\hline & Sig. (2-tailed) & & .000 & .000 & .000 \\
\hline & $\mathrm{N}$ & 326 & 326 & 326 & 326 \\
\hline \multirow{3}{*}{$\begin{array}{l}\text { Attitude towards } \\
\text { French }\end{array}$} & Pearson Correlation & $.266^{* *}$ & 1 & $-.277^{* *}$ & $-.270^{* *}$ \\
\hline & Sig. (2-tailed) & .000 & & .000 & .000 \\
\hline & $\mathrm{N}$ & 326 & 326 & 326 & 326 \\
\hline \multirow{3}{*}{$\begin{array}{l}\text { English } \\
\text { proficiency }\end{array}$} & Pearson Correlation & $-.235^{* *}$ & -.277 & 1 & $.293^{* *}$ \\
\hline & Sig. (2-tailed) & .000 & .000 & & .000 \\
\hline & $\mathrm{N}$ & 326 & 326 & 326 & 326 \\
\hline \multirow{3}{*}{$\begin{array}{l}\text { Attitude towards } \\
\text { English }\end{array}$} & Pearson Correlation & $-.323^{* *}$ & $-.270^{* *}$ & $.293^{* *}$ & 1 \\
\hline & Sig. (2-tailed) & .000 & .000 & .000 & \\
\hline & $\mathrm{N}$ & 326 & 326 & 326 & 326 \\
\hline
\end{tabular}

However, this statistically significant correlation between these variables is a negative correlation (-). This means that as one variable increases in value, the second variable decreases in value. That is to say, for instance, the higher a person's French proficiency level is getting, the lower his English proficiency is becoming and vice versa.

\subsection{Language practices}

The current section aims at eliciting the respondents' attitudes towards French and English by getting them to answer questions related to communication, foreign language learning and entertainment.

\subsubsection{Communication}

The aim of this sub-section is to explore firstly the participants' frequency of the use of French and English. In that, item 8 asks the participants to choose between French and English the one that they use more frequently in their daily interaction. Secondly, item 9 examines the language the participants think is effective when abroad. The results are exhibited in the following table:

Table 4. The language used most in daily interactions

\begin{tabular}{l|l|c|c|c|c}
\hline \multicolumn{2}{l|}{} & Frequency & Percent & Valid Percent & Cumulative Percent \\
\hline \multirow{3}{*}{ Valid } & French & 314 & 85.8 & 96.3 & 96.3 \\
\cline { 2 - 6 } & English & 12 & 3.3 & 3.7 & 100 \\
\hline \multirow{2}{*}{ Total } & 326 & 100 & & \\
\hline
\end{tabular}

Table 4 shows that the frequency of French use is much higher than the frequency of 


\section{Mahmoud Seddik}

English use. More specifically, the overwhelming majority of $96.3 \%$ state that they use French more than English.

The $9^{\text {th }}$ item tries to explore the respondents' beliefs about the most important language when they happen to be abroad. The results are displayed in the table below:

Table 5. Frequency of respondents' beliefs about the most useful language when abroad

\begin{tabular}{l|l|c|c|c|c}
\hline \multicolumn{2}{c|}{} & Frequency & Percent & Valid Percent & Cumulative Percent \\
\hline \multirow{2}{*}{ Valid } & French & 10 & 2.7 & 3.1 & 3.1 \\
\cline { 2 - 6 } & English & 316 & 86.3 & 96.9 & 100 \\
\hline Missing & System & 40 & 10.9 & & \\
\hline \multicolumn{2}{l}{ Total } & 366 & 100 & & \\
\hline
\end{tabular}

There seems to be a sort of consensus among the respondents that English is the most useful language when abroad. Clearly, Table 5 shows that the extreme majority of the respondents (96.9\%) think that it is English that seems important while only $3.1 \%$ believe it is French. These figures indicate that the respondents are aware of the lingua franca nature of the English language in the world. The tiny percent of those who believe that French is the most important language when abroad can be attributed to historical, economic and cultural ties with the Republic of France which, for many Moroccans, represents or stands for the whole Europe.

The current finding about French and English use frequency supports what has been revealed regarding the respondents' attitudes towards the two languages in the previous section. The higher frequency of French use in the respondents' daily interaction seems compatible with the better evaluations that were given to French on the three solidarity traits including the item 'French helps in daily communication'. On the other hand, the fact of perceiving English as a global language by the extreme majority of the respondents seems to confirm their favorable attitudes towards English based on the three status items including 'English is a global language'. Such compatibility does not only support the research hypothesis that there is a growing attitudinal tendency towards English promotion or upgrading and French demotion or downgrading, but it also adds up to the reliability of the current study and, thus, the possibility of generalizing these findings.

\subsubsection{French and English learning experience}

The fifth section of the questionnaire focuses on French and English as academic school subjects. The aim is to examine the respondents' French and English learning experiences through item 10. Item 11 and 12 seek to explore the language centers in the participants' cities. Item 13 and 14 look into the courses they want to take. Item 15 examines the respondents' preferred language of instruction and the last item explores the country where they want their children and/or themselves to pursue their studies. 


\section{French versus English: A sociolinguistic study of Moroccans'foreign language attitudinal tendencies}

As far as the $10^{\text {th }}$ item is concerned, the respondents were asked to evaluate their French and English experience in the light of three features and their opposites: difficult versus easy, boring versus interesting and classical versus modern. The results are exhibited in the table below:

Table 6. Frequencies of the respondents' attitudes towards French and English learning experience

\begin{tabular}{|c|c|c|c|c|c|}
\hline \multicolumn{2}{|c|}{ French learning experience } & Frequency & Percent & Valid Percent & Cumulative Percent \\
\hline \multirow{7}{*}{ Valid } & Difficult & 104 & 28.4 & 32.1 & 32.1 \\
\hline & Easy & 45 & 12.3 & 13.9 & 46.0 \\
\hline & Boring & 77 & 21 & 23.8 & 69.8 \\
\hline & Interesting & 46 & 12.6 & 14.2 & 84.0 \\
\hline & Classical & 40 & 10.9 & 12.3 & 96.3 \\
\hline & Modern & 12 & 3.3 & 3.7 & 100 \\
\hline & Total & & & 100 & \\
\hline \multicolumn{2}{|c|}{ English learning experience } & Frequency & Percent & Valid Percent & Cumulative Percent \\
\hline \multirow{7}{*}{ Valid } & Difficult & 33 & 9.0 & 10.1 & 10.1 \\
\hline & Easy & 123 & 33.6 & 37.7 & 47.9 \\
\hline & Boring & 20 & 5.5 & 6.1 & 54.0 \\
\hline & Interesting & 67 & 18.3 & 20.6 & 74.5 \\
\hline & Classical & 10 & 2.7 & 3.1 & 77.6 \\
\hline & Modern & 73 & 19.9 & 22.4 & 100 \\
\hline & Total & & & 100 & \\
\hline
\end{tabular}

Concerning the French learning experience, Table 6 shows that it has been described as "difficult" by $32.1 \%$ of the respondents while only $13.9 \%$ feel that it is an "easy" language to learn. Moreover, being "boring" comes second in the evaluative ranking chosen by $23.8 \%$ of the respondents while only $14.2 \%$ of the 326 participants think that it is "interesting" to learn. Finally, $10.9 \%$ of the respondents think that French is taught by adopting "classical" methodologies while only $12.3 \%$ believe that French learning is introduced in a "modern" way. The conclusion that can be drawn from the information in the chart is that the respondents generally think that their French learning experience is a negative experience. That is to say, 221 respondents $(68.2 \%)$ out of 326 believe that their French learning experience is difficult, boring or classical while only the remaining $103(31.8 \%)$ feel that it is easy, interesting or modern.

Regarding the English learning experience, the table above shows that English learning has been perceived as "easy" by $37.7 \%$ of the respondents while $10.1 \%$ think that it is a "difficult" experience. Moreover, the idea of being "modern" ranked second in the list chosen by $22.4 \%$ of the respondents while only $3.1 \%$ of the 326 participants feel that 


\section{Mahmoud Seddik}

English learning is introduced in a "classical" way. Finally, "interesting" comes third in the evaluative ranking opted for by $20.6 \%$ of the respondents while only $6.1 \%$ believe that English is a "boring" experience. The results obtained through item 10 indicate that the respondents generally think that their English learning experience is a positive experience. 263 respondents (80.7\%) out of 326 believe that their English learning experience is easy, interesting or modern while only the remaining 63 (19.3\%) feel that their English learning experience is difficult, boring /or classical.

In relation to language attitude evaluation, it should be noted that a remarkable number of the Moroccans' French and particularly English language repertoire is largely nourished through language classes. Believing that one's language learning has been an easy process, introduced in an interesting environment and through modern methodologies is likely to captivate the students and endear the language to them. Hence, part of the respondents' favorable attitudes towards English might be thanks to their English learning experience.

Later in the questionnaire, the respondents are asked through item 11, 12, 13 and 14 about foreign language schools/centers in their cities and whether or not they take or would like to take a foreign language course there and what language they would study. Given the long-held supposition among Moroccans that French has been used to name businesses, products ...etc. as a marketing strategy to attract customers, the current questions were posed primarily to find out if such a conviction is still prevailing or not.

Unanimously, all the respondents claim that they have language centers in their own cities. Unfortunately, only 177 out of 326 participants managed to write a name of a language center that they know. So, after a cursory reading of these names, it has been decided to group them into three categories according to the language used to name them: Arabic, French and English. As it has been made clear in Table 7, every language center's name is accompanied with a number that refers to how many times it was mentioned by the informants.

Among the 177 language centers that the respondents cited, $110(62.14 \%)$ were named in the English language while 63 (35.59\%) of these language centers' names were in French whereas only 4 (2.25\%) were given an Arabic name.

This current finding hints at the fact that the number of English courses offered is larger than French courses. That is to say, Moroccans' readiness to learn English seems stronger than their willingness to study French, and that may explain the use of English names in the centers' billboards. Furthermore, such a finding may also challenge the long-standing belief in Morocco that French is a powerful marketing strategy to implement at least in what pertains to language centers. In other words, English seems to start earning those features of persuasiveness, of credibility and of excellence that French has been cherishing among Moroccans for long. 
French versus English: A sociolinguistic study of Moroccans'foreign language attitudinal tendencies

Table 7. List of names of language schools

\begin{tabular}{|c|c|c|}
\hline Arabic & French & English \\
\hline - ALAM langues (3) & - Tour du Savoir (8) & - The ambassadors language center (6) \\
\hline \multirow[t]{9}{*}{ - Aqlam (1) } & - Club de langues vivantes (3) & - Etablisment Khomsi d’Anglais (3) \\
\hline & - Alpha Etoile (5) & - Shakespeare's corner (14) \\
\hline & - Institute Francais de Fes (33) & - Wisdom school (4) \\
\hline & - Institut sans Frontières des Langues (12) & - DELTA school (3) \\
\hline & - Centre Jacobson de Formation de & - American language center (51) \\
\hline & langues $(2)$ & - Nizar’s language school (8) \\
\hline & & - Moroccan Language School (8) \\
\hline & & - English Horizon (11) \\
\hline & & - Universe School (2) \\
\hline $4(2.25 \%)$ & $63(35.59 \%)$ & $110(62.14 \%)$ \\
\hline
\end{tabular}

The $13^{\text {th }}$ and the $14^{\text {th }}$ items in the questionnaire asked the respondents if they take or have taken a course(s) in one of those language centers (item 13) and which language they take or have taken (item 14). The result was that 109 (33.43\%) of the participants answered 'yes' and the other 217 (66.56\%) said 'no'. For the 109 who answered 'yes', 67 (61.46\%) of them stated that they were taking or have taken French courses in those language center while $42(38.53 \%)$ of them said that they were taking or have taken English courses.

The current finding, with reference to the respondents' evaluation of French and English, is suggestive of two ideas. To begin with, the respondents' willingness and readiness to enroll in language centers corroborate the participants' better evaluations of the two languages revealed in the previous section. Moreover, if French has been omnipresent in every aspect of the Moroccan life for almost a century, why would a student have extra courses in French? The first answer is in the French language strong presence that obliges Moroccans to enhance their French proficiency for various academic, professional and social purposes. The second possible answer would be in the teaching approaches and methodologies that were described, by the respondents themselves, as difficult, boring and classical and therefore, unsatisfactory and ineffective to attain a high level of proficiency required to be requited for a job. On the other hand, the respondents' exposure to English courses finds its explanation in the necessity to reinforce what has been learnt in the school English classes that are not sufficient to reach a high proficiency level.

\subsubsection{Entertainment}

Entertainment sources can also uncover some realities about the respondents' attitudes towards French and English. In this respect, to see the space that those two languages occupy during times of entertainment for Moroccans, the last section in the questionnaire 


\section{Mahmoud Seddik}

tries to explore the respondents' language of their most watched movies (item 17), their favorite movie (item 18) and the language of their favorite songs (item 19). The results are included in the following table:

Table 8 . Language of the most watched movies

\begin{tabular}{c|l|c|c|c}
\hline \multicolumn{2}{l|}{} & Frequency & Percent & Valid Percent \\
\hline \multirow{4}{*}{ Valid } & Arabic & 30 & 8.2 & 9.2 \\
\cline { 2 - 5 } & French & 12 & 3.3 & 3.7 \\
\cline { 2 - 5 } & English & 71 & 19.4 & 21.8 \\
\cline { 2 - 5 } & English movie dubbed into French & 35 & 9.6 & 10.7 \\
\cline { 2 - 5 } & English movies with Arabic subtitles & 178 & 48.6 & 54.6 \\
\hline \multirow{2}{*}{ Total } & 326 & 89.1 & 100.0 \\
\hline
\end{tabular}

Table 8 shows that $54.6 \%$ of the respondents reporting that they watch English language movies with Arabic subtitles. 21.8\% of them claim that they watch movies in English. 10.7\% of the informants claim that they watch English language movies dubbed into French.

Table 9. Crosstabulation of language of the most watched movies and age

\begin{tabular}{|c|c|c|c|c|}
\hline & & \multicolumn{2}{|c|}{ Age } & \multirow{2}{*}{ Total } \\
\hline & & above 45 & Less than 25 & \\
\hline \multirow{5}{*}{$\begin{array}{l}\text { language of the most } \\
\text { watched movies }\end{array}$} & Arabic & 11 & 19 & 30 \\
\hline & French & 10 & 2 & 12 \\
\hline & English & 0 & 71 & 71 \\
\hline & English movies dubbed into French... & 24 & 11 & 35 \\
\hline & English movies with Arabic subtitles... & 39 & 139 & 178 \\
\hline \multicolumn{2}{|l|}{ Total } & 84 & 242 & 326 \\
\hline
\end{tabular}

The cross-tabulation above further shows how these choices are distributed according to the respondents' age. The results show that the 'less than 25 age group' seem much more interested in English movies than the 'above 45 age group'. With regards to the young group, out of 242 respondents, 139 (57.43\%) assert that they watch English movies with Arabic subtitles while 71 (29.33\%) say that they watch movies in English. Moreover, 19 (7.85\%) of the participants report that they watch movies in Arabic, 11 (4.54\%) think that they watch English movies dubbed into French and finally only $2(0.82 \%)$ out of the total 242 respondents state that they watch movies in French. Concerning the 'above 45 of age group', out of 84 participants, 39 (46.42\%) seem interested in watching English movies with Arabic subtitles, 24 (28.57\%) in English movies dubbed into French. Also, 10 $(13.09 \%)$ think they watch movies in Arabic, 10 (9.90\%) seem interested in watching movies in French and no one seems interested in watching movies in English.

As an extension to the previous item, item 18 in the questionnaire seeks to explore the 
respondents' favorite movies. The results show that out of 163 answers obtained, 93 of these movies were American or British movies, 43 were Turkish, 16 of those films were Egyptian, 8 were Korean and 3 were Moroccan. This is a clear indication not only of the linguistic spread of English in Moroccan homes, but of the cultural growth of the American culture as well. For instance, American films such as: 'fast and furious', 'Lord of the Rings', 'mission: impossible', 'Avengers', 'Transformers' ...etc. are only examples among numerous others mentioned by the respondents that reflect their admiration of the American professionalism, creativity, lifestyle and many other cultural aspects including language.

In addition to movies, songs can also hint at the respondents' language attitude. In that, item 19 asks the respondents about the language of their favorite songs and the outcome as exhibited in Table 10 reveal that $40.3 \%$ of the respondents believe that they like listening to songs in Arabic while 8.3\% think that they prefer songs in French whereas English songs seem to appeal to $51.4 \%$ of the respondents.

Table 10. Language of songs

\begin{tabular}{l|l|c|c|c|c}
\hline \multicolumn{2}{c|}{} & Frequency & Percent & Valid Percent & Cumulative Percent \\
\hline \multirow{4}{*}{ Valid } & Arabic & 131 & 35.8 & 40.3 & 40.3 \\
\cline { 2 - 6 } & French & 27 & 7.4 & 8.3 & 48.6 \\
\cline { 2 - 6 } & English & 167 & 45.6 & 51.4 & 100 \\
\hline \multirow{2}{*}{ Total } & 325 & 88.8 & & \\
\hline
\end{tabular}

To understand how these preferences are distributed according to the respondents' age, a crosstabulation was extracted and the results show that English appeals to the young generation more than the old one. Among the 242 young respondents, 158 (65.28\%) expressed their interest in songs in English while only 9 (10.71\%) out of the 84 old respondents stated that they listen to songs in English.

Table 11. Crosstabulation of language of songs listened to and age

\begin{tabular}{l|l|c|c|c}
\hline \multicolumn{2}{c}{} & \multicolumn{2}{|c}{ Age } & \multirow{2}{*}{ Total } \\
\cline { 3 - 5 } \multicolumn{2}{c|}{} & above 45 & Less than 25 & 131 \\
\hline \multirow{3}{*}{\begin{tabular}{l}
\multirow{2}{*}{ Language of songs listened to } \\
\cline { 2 - 5 }
\end{tabular}} & French & 55 & 76 & 27 \\
\cline { 2 - 5 } & English & 9 & 8 & 167 \\
\hline \multicolumn{2}{l|}{ Total } & 83 & 242 & 325 \\
\hline
\end{tabular}

The respondents' personal preferences about the movies they watch and the songs they listen to reflect a specific attitudinal tendency. The American pop culture, globalized by movies, songs and social media, appears to captivate the younger generations that seem to have already started a process of assimilating and conditioning to the patterns, conventions, 


\section{Mahmoud Seddik}

and systems of the new culture. Perceiving English favorably by the sweeping majority of the respondents is a manifestation of this cultural adjustment or adaptation.

The current figures regarding the respondents' preferences of entertainment sources provide a good interpretation to the finding that English is perceived also favorable on the solidarity traits. In the light of this finding, we understand now how English starts earning features of familiarity and closeness. That is to say, Moroccans, through their exposure to the American movies and songs, may pick up certain expressions and automatically keep using them or at least they become accustomed to the English language being present at home.

\section{Discussion of results}

The results obtained through the language questionnaire are suggestive, with varying degrees, of unequivocally favorable attitudes towards both French and English. Such favorableness of the respondents' attitudes towards both languages was also obvious in their self-evaluation of the French and the English proficiency. In that, the majority of the respondents thought that their French and English proficiency ranges from average to good. This comes as no surprise since, academically, the coefficient of French as a school subject is high enough to affect the students' overall school grade. Professionally, French is a prerequisite either to get a decent job or ascend the professional ladder. Socially, a good level in French is likely to smoothen and speed up one's daily activities in the Moroccan administrations, where French is wellentrenched. Also, the English proficiency level among the respondents was expected in this study, given the phenomenal spread of English globally and locally, the growing interest to learn it, the wide exposure among teenagers and adults to the English language media, the spread of the English language centers, in addition to the educational legislations to improve its status as a school subject. All these factors encourage young Moroccans to be proficient in English. In sum, a certain degree of proficiency or excellence in a language is generally suggestive of certain motivational processes and cognitive readiness that allow a person to implicitly construct favorable attitudes towards that language and, therefore, devote time and energy to excel in it. Nevertheless, the results showed that there was some variation in the respondents' positive evaluation of the two languages. To illustrate, the findings of the language questionnaire English was rated higher than the French language. That is to say, the English language has been perceived better and then rated higher in contrast to the French language. As a result, the current finding supports the research's first hypothesis that the Moroccans' foreign language attitudinal tendencies are shaping up towards favoring English at the expense of French. 
According to a number of Moroccan studies (Bentahila, 1983; Mouhssine, 1995; Marley, 2004), Moroccans, for decades, have perceived French as a language that enjoys a high prestige, as a symbol of intellectuality, a sign of civilization and a path to progress. English seems to have come to seize those attributes instead of, or share them alongside, French at the Moroccans' foreign language attitudinal level. Such a meaningful language attitudinal trend towards English preference instead of French can be attributed to a plethora of factors. Firstly, Moroccans from all walks of life are aware of the achievements of the English-speaking world in the field of business, education, art, science and technology. Needless to say that English is the first international language of business, media, communication and international services. Secondly, the results obtained through communication section in the questionnaire showed that when asked about their beliefs about the most important language when abroad, the extreme majority of the respondents reported that it was English while only 3.1\% thought it was French. This is indicative of the respondents' mindfulness of the lingua franca nature of the English language. For instance, a Moroccan businessman may meet with his Brazilian counterpart in Germany and they can communicate, negotiate and make deals without a word in Arabic or Portuguese or German; they will automatically start using English. Therefore, English in this context acts like a linguistic passport that would spare tourists, businessmen, statesmen, lecturers and many others the awkwardness or inconvenience of miscommunication or misunderstanding. Furthermore, another reason that stimulates this ongoing language attitudinal trend is the Moroccans' widespread exposure to English TV programs, American movies, social media, books, journals and other publications either for enjoyment or for cultural purposes. As a matter of fact, the substantiality and significance of these reasons make the language associated with highly substantial and very significant for Moroccans as well.

The fifth section in the questionnaire that focuses on the respondents' foreign language learning experience and their views about the language centers in their cities, offers another interesting explanation of the seemingly ongoing language attitudinal bias in favor of English. The findings that have been uncovered by the study show that Moroccans' French learning experience is somehow described as difficult, boring and classical in contrast to the English learning experience that has been described as easy, interesting and modern. The significance of this information comes from the fact that the Moroccans' French and particularly English language repertoire is largely the product of language classes. So, believing that one's own language learning has been an easy process, introduced in an interesting environment and through modern methodologies, is likely to captivate the students and endear the language to them. Hence, part of the respondents' favorable attitudes towards English might be due to their productive English learning experience while part of the less positive attitudes towards French might be due to their unhelpful 


\section{Mahmoud Seddik}

French learning experience. This might be obvious with the French didactics in Morocco. For all our respondents, learning French is usually associated with a lot of manipulative drills of complicated grammatical structures, and memorization of verb conjugation. And what makes of the experience generally difficult and somehow a 'boring' one, as reported by the informants, is the tradition that the same teacher teaches French and mathematics in the same session in primary school levels. So, a student at an early age might easily get bored and even exhausted finishing the "le discours direct / le discours indirect" lessons only to end up starting the new half of a session working on the arithmetic of multiplication and division. In addition to the purely linguistic and pedagogical factors, socio-political motives also have their share. That is to say, the growing tendency to favor English over French is only one of the symptoms of the strained relation between the dominant social classes in Morocco and the French language. To explain, on behalf of the masses, the conservative parties often sell to the public the idea that French is a threat to the national identity and it is a sign that the country has not fully reached its independence (Grandguillaume, 1983). Also, French sometimes crops up as a subject of class struggle in Morocco. It is often claimed by the masses that French is responsible for the inequality of opportunities in the country as it serves mostly the Francophone elite and the ruling class whose children study in French schools. In sum, the informants' positive attitudes towards English and less positive towards French might be a reaction to the continuous clash of interests over French.

The results obtained demonstrate that the females hold more favorable attitudes towards French and English than their male counterparts. In all the three studies conducted, the results revealed that the females' ratings of the French and the English language/guise were higher than the males' ratings. Moreover, the female respondents have rated English higher than French in all the three studies, and so was the case among the males who also seem to have rated English better than French. The statistically significant difference between the male and the female evaluations as revealed in the language questionnaire and the matched guise study $\mathrm{n}^{\circ} 2$ is indicative of the influence of gender in shaping the Moroccans' attitudinal tendencies towards the English preference.

The results of the study also revealed that the leading role of the female respondents in the overall evaluation of French and English appears to be self-evident. Let's start with French. The findings showed that the language was rated higher by the females than the males on the first three solidarity traits. The female respondents' inclination to consider the French language as rich, beautiful, helpful, elegant, sociable, prestigious may emanate from their womanly nature. Commonly, qualities such as elegance, prestige, beauty and sociability hold some enchantment for females more than males. Actually, it has been found that females are socialized to be emotional, nonaggressive and context-oriented, 
whereas boys are socialized to be unemotional, aggressive, and achievement-oriented as a product of social conditioning processes (Chaplin \& Aldao, 2012; Wester, Vogel \& Pressly et al., 2002). By the same token, the female participants seem to consider French as an integral element of their life.

It is simply reminiscent of a memory, of a film, a song, a context in French classes or emotional ties with family in France... etc. Therefore, it is for these possible reasons that French seems to enjoy characteristics of intimacy among the female respondents more than the male respondents. Likewise, the unfavorable attitude towards French on the status dimension seems to be influenced more by the females' attitudes than the males'. That is to say, French seems to start losing its features of supremacy, modernity and power particularly among the females. The female respondents might be more cognizant of the vitality of language, alert to its subtleties and, therefore, more likely to respond with favor or disfavor than the male respondents. In a word, the female participants seem to act as a catalyzer for the ongoing foreign language attitudinal tendency to associate French with solidarity features instead of status features. Regarding English, the findings of the language questionnaire portrayed the female respondents as instigators of the ongoing language attitudinal disposition towards favoring English. As far as solidarity dimension is concerned, the female respondents rated English lower than French, but higher than their male counterparts. This outcome finds its justification in the little contact that the respondents have with English. In spite of its growing popularity, the language is still being viewed as a school subject that students should master mostly to pass exams. Surprisingly, despite this very little contact, English seems to be perceived favorably on the solidarity traits as if the respondents feel some sort of familiarity and intimacy with English. There are two possible explanations for this finding. Firstly, the respondents' attitudes towards English may not necessarily be connected to or aligned with the solidarity dimension. Clearly, English for the majority of Moroccans is classroom bound and if it happens to be used in authentic contexts, it is done mostly to receive input and not to produce real life output. To put it differently, assuming that English is a language that enjoys some characteristics of familiarity and close proximity technically is inconsistent with the fact that English doesn't enjoy the popularity and the usefulness that would make of it familiar and common in the Moroccan community just like the case with French. We hypothesize that there might be another dimension to refer to a future attitudinal state based on one's calculations of events and circumstances. In short, evaluating English as a language that is very useful in daily interactions is socio-linguistically inaccurate unless seen from the respondents' future perspective that might reflect their pragmatic attitudes. Secondly, the respondents, indeed, do have positive attitudes towards English on the solidarity dimension. That is to say, in stark contrast to the previous interpretation, the language is somehow 


\section{Mahmoud Seddik}

perceived as possessing some attributes of sociability and familiarity among Moroccans. The veracity of this assumption can be found in the new popular culture brought about by globalization. In Morocco, English has permeated through the Moroccan society seamlessly, but powerfully. Movies and songs in the English language top young Moroccans' list of preferences of these programs. This is supported by item 17, 18 and 19 in the language questionnaire where $54.6 \%$ of the respondents reported that they watch movies in English with Arabic subtitles, $21.8 \%$ said that they watch movies in English and $51.4 \%$ of the informants reported that they like listening to songs in English. Therefore, the English dominance over the popular media is likely to make English words, expressions and even lifestyle pervasive at home and street. Interestingly, the American pop culture, globalized by movies, songs and social media, appears to captivate the young generations that seem to have already started a process of assimilating and conditioning to the patterns, conventions, and systems of the new culture. Perceiving English favorably by the sweeping majority of the young respondents is a manifestation of this cultural adjustment or adaptation. In a nutshell, the act of creeping into these lower domains of home and street implies that Moroccans have built or are in the process of building a new relationship with English associated with closeness and familiarity, which are categorized as solidarity traits. Regarding the status dimension, English was evaluated also more favorably by the female respondents than their male counterparts in all the three studies. Similar to the French evaluation, the female respondents' impact is obvious on their status evaluations of English.

Age turned to have a significant impact on the respondents' attitudes towards French and English. The ongoing language attitudinal tendency seems to be generationally-driven. The respondents 'above 45' of age rated French higher than English whereas those 'below 25' of age rated English higher than French. That is to say, the older the person, the higher he is expected to rate French compared to English and the younger the person, the higher he is expected to rate English compared to French. The exploration of the elderly participants' motives behind their favorable attitudes towards French presented two possible interpretations. Firstly, French for this age group has been a constituent part of their life stages. They had been instructed completely or partially in French, a fact which made of it, with varying degrees, their practical language when working, when communicating and/or even when entertaining. Therefore, through the course of their academic, professional and social life, the elderly appear to have built a pretty strong connection with French and an unfaltering loyalty to it. Secondly, in the Moroccan society, French for the elderly sometimes constitutes a sort of symbolic capital that distinguishes them from those who don't have it. It is common among the elderly that being taught completely in French and by French teachers is nostalgically and proudly being used as an argument to show 
knowledge, competence and even superiority over the young generation. In this regard, many psychologists propose that people become increasingly conservative and gradually resistant to change as they get older (Glenn, 1974; Sears, 1981). In relation to language attitudes in Morocco, this group of people become less tolerant towards language innovations, resilient to change and proud of the simple things that made up their life. Therefore, a simple change in attitudes towards French among the elderly Moroccans may entail abandoning all the symbolic values associated with it. However, given this assumed attitudinal inflexibility among the old people to change their perception of French, how can we explain their positive attitude towards English? The life-long openness hypothesis (Sears, 1981) provides the answer when proposing that vulnerability to attitude change could decrease across the life cycle, but it may never reach a zero level. That is to say, there will always be room for the elderly to change their attitudes towards a language or build new ones as long as they encounter either the attitude object itself or information about it (Eagly \& Chaiken, 1998; Baker, 1992). Unlike the elderly participants, most of the young informants grew up in a globalized environment, where the American pop culture was the fashion. English, herein, has been functioning as a major promulgator of this new westernized lifestyle that appeals mostly to adolescents and adults, and that is what explains their favorable attitude towards English. In relation to language attitudinal change, are young people's perceptions of English vulnerable to change? The impressionable years hypothesis proposes that individuals are highly susceptible to attitude change during late adolescence and early adulthood (Easton \& Dennis, 1969; Hess \& Torney, 1967). In the Moroccan case, young people's academic aspirations, professional development and immigration motives are more or less connected with language. Nowadays, English is worth the favorable attitudes people have towards it as long as it is a language of science, business and social mobility. That is to say, once English loses these qualities to another language, young Moroccans would probably change their attitudes, but if it maintains its high status in the years to come, the present young generation in two or three decades will cling to English being the language that marked their childhood and adulthood and wrangle in its favor against the growth of Mandarin Chinese that is likely to be admired by the coming generations. In a nutshell, given the favorableness that English is enjoying among the young generation and taking into account their attitudinal flexibility, it can be assumed that it is the young generation that instigates and fuels the ongoing foreign language attitudinal tendency towards English preference at the expense of French.

\section{Conclusion}

The current investigation has explored 326 Moroccan respondents' language attitudinal tendencies towards French and English through a language questionnaire. More specifically, 


\section{Mahmoud Seddik}

the 19 items of the questionnaire addressed five major elements: firstly, the respondents' French and English proficiency. The results of this section showed that the majority of the respondents generally thought that their French proficiency and English proficiency range from average to good. Secondly, the exploration of the respondents' attitudes towards French and English revealed that they do hold favorable attitudes towards French and very favorable attitudes towards English. Regarding whether or not gender has any effect on these evaluations, the Chi-square tests of association confirmed that, except for one item, there was a significant association between gender and the respondents' attitudes towards French and their attitudes towards English. As for the effect of age, the results obtained confirmed that, except for one item, there was a significant association between age and the respondents' attitudes towards French and English. Thirdly, the results obtained from the language questionnaire showed that the frequency of French use is much higher than the frequency of the English use. However, the results showed that the extreme majority of the respondents admitted that English is the most essential language when they happen to be abroad. Fourthly, the respondents' language learning experience exploration revealed that the respondents treasure very positive experiences towards English, unlike their French learning experience. Finally, the findings revealed that the overwhelming majority of the young respondents seem much interested in watching movies in English and listening to English songs, unlike their elders who seemed loyal to Arabic and French. In a nutshell, the findings revealed by the current study are an indication of the ongoing attitudinal trend among Moroccans towards favoring English at the expense of French.

\section{References}

Appel, R. \& P. Muysken. 1987. Language Contact and Bilingualism [M]. London: Edward Arnold.

Baker, C. 1992. Attitudes and Language [M]. Clevedon, UK: Multilingual Matters.

Bentahila, A. 1983. Language Attitudes among Arabic-French Bilinguals in Morocco [M]. Clevedon: Multilingual Matters.

Chaplin, T. \& A. Aldao. 2012. Gender Differences in Emotion Expression in Children: A meta-analytic review [J]. Psychological Bulletin, 139(4):735-765.

Eagly, A. H. \& S. Chaiken. 1998. Attitude Structure and Function [A]. In D. T. Gilbert, S. T. Fiske \& G. Lindzey (eds.). The Handbook of Social Psychology [C]. New York: McGraw-Hill, 269-322.

Easton, D. \& J. Dennis. 1969. Children in the Political System: Origins of political legitimacy [M]. New York: McGraw-Hill.

Gardner, R. C. 1985. Social Psychology and Second Language Learning: The role of attitudes and motivation [M]. London: Edward Arnold.

Glenn, N. D. 1974. Aging and Conservatism [J]. The Annals of the American Academy of Political and Social Science, 415:176-186.

Grandguillaume, G. 1983. Arabisation et Politique Linguistique au Maghreb [M]. Paris: Maisoneuve et Larose.

Hess, R. D. \& J. V. Torney. 1967. The Development of Political Attitudes in Children [M]. Chicago: Aldine. Likert, R. 1932. A Technique for the Measurement of Attitudes [J]. Archives of Psychology, 140:5-55.

Marley, D. 2004. Language Attitudes in Morocco Following Recent Changes in Language Policy [J]. 


\section{French versus English: A sociolinguistic study of Moroccans'foreign language attitudinal tendencies}

Language Policy, 3(1):25-46.

Mouhssine, O. 1995. Ambivalence du Discourse sur L'arabisation [J]. International Journal of Sociology of Language, 112:45-62.

Ryan, E. B., H. Giles \& R. J. Sebastian. 1982. An Integrative Perspective for the Study of Attitudes towards Language Variation [A]. In E. B. Ryan \& H. Giles (eds.) Attitudes towards Language Variation: Social and applied contexts [C]. London: Edward Arnold, 1-19.

Sadiqi, F. 1991. The Spread of English in Morocco [J]. International Journal of the Sociology of Language, 87(1):99-114.

Sears, D. O. 1981. Life-Stage Effects on Attitude Change, Especially Among the Elderly [A]. In S. B. Kiesler, J. N. Morgan \& V. K. Oppenheimer (eds.). Aging: Social change [C]. New York: Academic Press, 183-204.

Wester, S., D. L. Vogel, P. K. Pressly \& M. Heesacker. 2002. Sex Differences in Emotion: A critical review of the literature and implications for counseling psychology [J]. The Counseling Psychologist, 30(4): 630-652.

\section{Appendix: Language Attitude Questionnaire}

\section{Background Information}

1- Gender:

2- Age:

male:

less than 25 female:

above 40:

II. Language Mastery

3- Please judge your level of competence in French and English. Please rate yourself on a scale from 1 to 5 , with 1 meaning 'very poor, and 5 meaning 'very good'. Circle the number that best corresponds to your competence.

\begin{tabular}{|l|l|l|l|l|l|}
\hline & very poor & & & & Excellent \\
\hline The French language & 1 & 2 & 3 & 4 & 5 \\
\hline & very poor & & & & Excellent \\
\hline The English language & 1 & 2 & 3 & 4 & 5 \\
\hline
\end{tabular}

\section{Language Evaluation}

Here are some statements about the French and the English language. For each statement, please say if you agree or not by putting a cross in the box which most corresponds to your point of view. 4- The French language :

\begin{tabular}{|l|l|l|l|l|l|}
\hline & $\begin{array}{l}1=\text { Disagree } \\
\text { Completely }\end{array}$ & $2=$ Disagree & $3=$ Neutral & $4=$ Agree & $\begin{array}{l}5=\text { Agree } \\
\text { Completely }\end{array}$ \\
\hline -French is a rich language & & & & & \\
\hline -French is a beautiful language & & & & & \\
\hline -French is helpful in daily communication & & & & & \\
\hline -French is an international language & & & & & \\
\hline -French is able to follow modernization & & & & & \\
\hline -French is important in the job market & & & & & \\
\hline
\end{tabular}

5- Write one single word that you think is the most suitable to describe the French language?

6- The English language :

\begin{tabular}{|l|l|l|l|l|l|}
\hline & $\begin{array}{l}1=\text { Disagre } \\
\text { completely }\end{array}$ & $2=$ disagree & $3=$ Neutral & $4=$ Agree & $\begin{array}{l}5=\text { Agree } \\
\text { completely }\end{array}$ \\
\hline -English is a rich language & & & & & \\
\hline -English is a beautiful language & & & & & \\
\hline -English is helpful in daily communication & & & & & \\
\hline -English is an international language & & & & & \\
\hline -English is able to follow modernization & & & & & \\
\hline -English is important in the job market & & & & & \\
\hline
\end{tabular}




\section{Mahmoud Seddik}

7- Write one single word that you think is the most suitable to describe the English language?

\section{Communication}

8- What is the frequency of using these languages in your daily life? Answer by circling the number that most corresponds to your point of view.

\begin{tabular}{|l|l|l|l|l|l|}
\hline & Never & Sometimes & Often & Usually & Always \\
\hline The French language & 1 & 2 & 3 & 4 & 5 \\
\hline The English language & Never & Sometimes & Often & Usually & Always \\
\hline
\end{tabular}

9- What is the language of communication that you find appropriate when abroad?

$$
\text { French: }
$$

English:

\section{Foreign Language Learning}

10- How can you describe your experience in learning these languages? Put a tick in the right box that best corresponds to your viewpoint:

\begin{tabular}{|l|l|l|l|l|l|l|}
\hline & Easy & Difficult & Boring & Interesting & Classical & Modern \\
\hline The French language & & & & & & \\
\hline & Easy & Difficult & Boring & Interesting & Classical & Modern \\
\hline The English language & & & & & & \\
\hline
\end{tabular}

$11-$ Is there any language center in your city?

$$
\text { Yes: }
$$

$\square$ of these language center

No:

12- If yes, please give a name of one of these language centers.

13- Have you ever taken courses in one of these language centers?

$$
\text { Yes: } \square \quad \text { No: }
$$

14- If yes, which language have you taken courses in?

$$
\text { French: }
$$

15- In the future, do you prefer your kids to be taught in:

$$
\text { French }
$$

English:

\section{English:}

16- In case, you or your children had a chance to study abroad, what is the appropriate country for that in your opinion?-

\section{Entertainment}

17- Most of films I watch are in: (choose only one option)

\begin{tabular}{|l|l|l|l|}
\hline Arabic & & English dubbed in French & \\
\hline French & & English with Arabic subtitles & \\
\hline English & English dubbed in Arabic & \\
\hline
\end{tabular}

18- Most of songs I listen to are :
Arabic:
French:

19- What is

Arabic: ion you use in social media:

French:
English:

English: 